
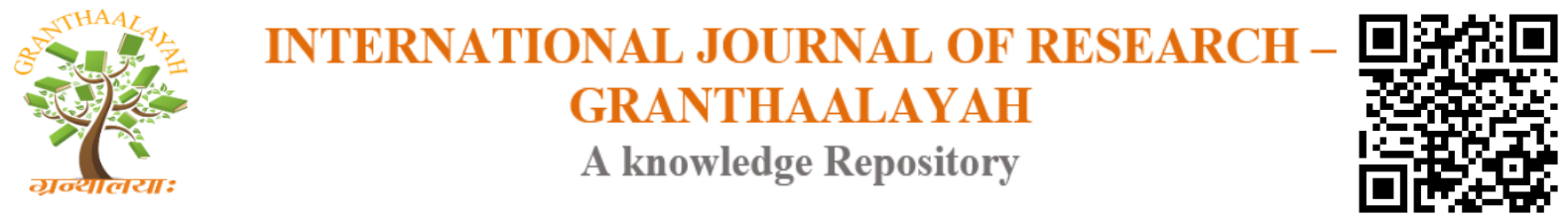

Science

\title{
EXPERIENTIAL LEARNING ACTIVITIES: A POTENTIAL TOOL FOR GREEN CATALYST
}

\author{
Prashant Thote ${ }^{* 1}$, Gowri. $\mathrm{S}^{2}$ \\ *1,2 Gyanodaya Vidya Mandir, India
}

\begin{abstract}
Education is the process of continuous comprehensive evolution which dynamically adopts its vision, structure, objectives and problems in order to solve the challenges. Experiential learning is the learning by doing through experience, exploration, innovation and natural skills, creativity and self-confidence. The purpose of the present paper is to determine effect of experiential learning model on student's conceptual understanding on impact of climate change on raise in sea level. The sample of the study was 50 students of grade IX. Questionnaire and interviews are used to collect the data. Result of the study reveals that experiential learning is effective pedagogical tool to address misconception and enhance conceptual understanding.
\end{abstract}

Keywords: Understanding; Misconception; Global Warming; Students; Science.

Cite This Article: Prashant Thote, and Gowri. S. (2020). "EXPERIENTIAL LEARNING ACTIVITIES: A POTENTIAL TOOL FOR GREEN CATALYST." International Journal of Research - Granthaalayah, 8(4), 173-180. https://doi.org/10.29121/granthaalayah.v8.i4.2020.23.

\section{Introduction}

Students in classroom do not learn by the same way. Experience is the outcome of learning. To address the individual differences of heterogeneous class-room appropriate learning climate is essential. The heterogeneous characteristics of class-room of the students are replicated in the process of learning. Individual differences in learning process are addressed by experiential learning in the classroom. According to experiential learning theory learning is a process consisting of four processes. Experiential learning cycle must be structured from concrete experiencing to observation, abstract conceptualization to active experimentation. Concrete experiences are converted into abstract concepts and use in attaining new experience.

Experiential learning activities is an effective pedagogical approach because it develops student's meta-cognitive skills, enhances skills through application of the knowledge to real life situation and giving an opportunity to students for self-learning.

Experiential learning validation and internalization change in students and development are ensured. Experiential learning activities required appropriate planning to cover all learning ways. 
To gain concrete experience students active participation is essential. Reflective observation helps students to develop broad spectrum of perspective. The abstract conceptualization required attainment of knowledge of theory/principles by students. For effective and efficient conduction of experiment students must apply their knowledge and skills. Experiential learning cycle includes four stages such as reflective observation, concrete experience, active experimental phase and abstract conceptualization. In concrete experimental phase students require special situations to participate in events. Hence content/activity must be relevant to life. Reflective observation is analyzing and finding best possible solution for the problem. The learning through concepts, logic and concrete experience are focused during abstract conceptualization. Experiential learning activities must be appropriate. During active participation observation and listening are equally important. Students always understand the joy in useful learning process.

- First Phase: Students gain concrete experience from related topic.

- Second Phase: Attaining unique prospective towards gained experience.

- Third Phase: Comprehend logical structure through learning experience.

- Fourth Phase: Active experimentation.

Learning is continuous and life-long process. All individual need to learn, judge, interpret the situation which they experience in real life.

\section{Role of a Teacher}

As compared to traditional chalk and talk method in the experiential learning activities role of the teacher is different. In traditional chalk and talk method teacher is authoritative and their main job is to transmit the knowledge. In experiential learning activities teacher's role is counseling and seeking most appropriate and acquire experience and adequate resource. Emotional and physical safety of students to facilitate learning process. Teacher must be able to identify, motivate, recognize, stimulate and encourage spontaneous learning opportunities and active involvement in difficult situations, experimenting and finding best possible solution. Teacher foster students observation, connection between one content to another as well as theory/principle and experience and stimulate initiative among students. Experiential learning activities involves observation, brain-storming, numerical ability, case study, role-playing, stimulation, presentation, games and team work. It is essential to carefully select experiential learning activities with greatest learning potential and provides an opportunity for students for gaining new skills, deeper emerging, facing non-predictable situation, learning from mistakes and natural consequences. Role of teacher is like a philosopher, guide, and facilitator in learning process.

\section{Role of Students}

Student is a centre in the learning process. Experiential learning activities must generate interest in students for the active participation, motivate to ask questions, to experiment, to show curiosity, make self-decision and responsible for result. Students must reflect on leaning all lead to analysis, turn to good values, nurture critical thinking and synthetic abilities. Students must be able to understand theory and application in real life situation. The intellectual, emotional, social, physical participation of students trigger individual change of cognitive, affective, social acquisition. Student-teacher relationships are more strong and serviced. Students must apply basic knowledge to build new experience. Students are major beneficiary in experiential learning activities and 
setting teacher role activities. Students actively participate, respond, gets motivated and joyful during experiential learning activities.

\section{Methods}

\section{Research Question:}

The following research questions are designed to guide the study.

1) Does the experiential learning activity help students to their conceptual understanding of sea level rise?

2) How do students use experiential learning activities as learning strategies?

\section{Research Design}

The qualitative research method is used. The mixed design is employed. Two-phased experimental mixed design is applied to answer the research questions of the present study.

To answer the research question one: Does the experiential learning help students to have conceptual understanding of reason for sea level rise? - the data is collected and analyzed in three steps:

Pre-testing: The students conception on reason for sea level rise. (qualitative).

An intervention: Qualitative plus quantitative experiential learning activities to address the conceptual understanding.

Post-test: Students perception of the reason for sea level rise (Qualitative).

Reflection: Quantitative and qualitative intervention strategy is used to answer the research question one.

Question two: How do students use experiential learning activities a learning statistics?

Qualitative and quantitative method is applied to collect the data to answer research question tow. The unlimited comment and an opened field questions are linked to answer to sets of question of proceeding: Answer and explain your choice?

Tool: The present study collected and analyzed three types of data:

- Written open ended data of student's previous knowledge and video recording of nonformal discussions.

- The well-designed experiential learning activities task sheet and video recording of classroom discussions.

Written record of reflection questions.

\section{Use of Tool and Data Analysis}

First

Students are asked to write reasons for rise in sea level due to global warming/climate change. Random discussion held with students and recorded to clarify this opinion about rise of sea level. The data analyzed by using qualitative method. 


\section{Second}

The experiential learning activities were fabricated. The class of 40 studnets is divided into eight groups. The experiential learning activities and work sheet were completed in groups. The experiential learning activities were developed to have conceptual understanding about rise in sea level to students of class IX. Data is analyzed by using qualitatively and quantitatively to add meaning to students concepts.

\section{Third}

The experiential learning activities were completed. The slide was shown to the students on how the increase in temperature affected the ecological environment of earth. Students were asked to fill the questionnaire included both open ended and extended response type questions. The questionnaire had following set of questions:

1) On increasing sea level, how will our life be affected? Thermal expansion of the ocean, melting floating ice, melting land-based ice

2) Is there any query that exists in your mind to discover more about the issues in context to rise in sea level?

3) How would you rate experiential learning activities in fostering conceptual understanding of the reason for the rise of sea level?

(likert scale type is use to rate responses)

Very useful, useful, somewhat useful, not useful

Explain your response?

\section{Sample}

Total 40 students of academic year 2019-20 participated in the present study.

\section{Experiential Learning Activities}

Three experiential learning activities are designed to investigate the possible reasons for rise in sea level. The misconception exists among students about the rise in sea level. In practice actual reasons for raise in sea level are melting land base ice (glaciers) and thermal expansion. The misconception creates a conflict in cognitive which may impact a student's mitigation and adaption skills.

\section{Experiential Learning Activities: 1}

Investigate the impact on rise in sea level by melting of ice floating

1) Take used plastic glass and fill with water.

2) Add 5-6 ice cubes in glass till the water overflowed.

3) Dry the face of the glass after the water was spilled over.

4) When ice melts, ask students to observe rise in water level.

\section{Experiential Learning Activities: 2}

Investigate the impact of melting land bounded ice on rise in sea level

1) Take baking tray and fill with water.

2) Take a small size rod and put in the middle of the baking tree to represent mountain/land. Mark the level in the baking tray. 
3) Put bigger block of ice on rods. Ice is symbol of ice-sheet such as ice that covers the Antarctica.

4) As time passes, ice starts melting and asks students to observe water level in baking tray.

\section{Experiential Learning Activities: 3}

Investing impact of heat on sea level

1) Take the stopper lid of juice bottle and make small hole in it.

2) Place the straw on the hole and carefully seal the bottle. So under and top with small quantity of blue

3) The flask filled with almost to the brim with water and added a few drops to make colour.

4) Place the lid/stopper, tightly close the bottle and seal it carefully with blue tape.

5) Place the sealed bottle for two hours in sun and observe.

All above three activities are completed by students in group. All students are asked to complete the questions by predicting with proper reason before commencing the experiential leaning activities one after the other. All students are asked to complete their experiential learning activity task sheet after completing the activities. In explanation stage, when students are reconciling their prediction with their observation, students are motivated to encourage, analyze, stimulate, compare, contrast and criticize other group's opinion. During explanation phase researcher made observation and actively interacted with group.

All students were engrossed in explanation phase, prediction and explanation phase of the experiential learning activities and researcher recorded the explanation. As per the requirement the researcher asked questions to get clarity of thought, and always kept in mind that not to divulge the answer so that it may lead the students to accept the idea.

\section{Result and Discussion}

Result of the study reveals that students are in the opinion that prime cause for the rise in sea level is due to melting iceberg/ice-caps/glaciers.

The ice-caps, ice-bergs and glaciers are frozen water and melting of ice; do not make any difference and ice melt due to heat. All students are in the opinion during discussion that earth is hearting due to climate change. The ice melts as a result of excess heat absorption. Students are able to co-relate the element responsible for the rise in sea level is thermal expansion which is not in line and contradict with their prediction which they learnt from the three experiential learning activities.

The $80 \%(n=40)$ had an opinion that water will overflow out of the cup but $20 \%(n=10)$ had an opinion that water level will go down. The most common reasoning for prediction are summarized in Table -1 
Table 1: Reasons for prediction

\begin{tabular}{|l|l|l|}
\hline & Water level- water flow out of the cup & Water lever - go down \\
\hline$\%$ and $\mathrm{n}$ & $80 \%(\mathrm{n}=40)$ & $20 \%(\mathrm{n}=10)$ \\
\hline Reason & $\begin{array}{l}\text {-ice melt and change state } \\
\text {-water will add in glass }\end{array}$ & $\begin{array}{l}\text { Water in solid state will } \\
\text { take more volume than } \\
\text { in liquid state }\end{array}$ \\
\hline Explanation & $\begin{array}{l}\text {-ice melting and not over because melting cover space. } \\
\text { It taken up by frozen ice }(60 \%, \mathrm{n}=30) \\
\text { - water in liquid state has open cage structure- has } \\
\text { verse void, water particles move away from one } \\
\text { another, therefore it occupied in cup and do not } \\
\text { overflow }(20 \%, \mathrm{n}=10)\end{array}$ & $\begin{array}{l}\text { The amount of volume } \\
\text { taken ice is greater } \\
\text { when it is in liquid form }\end{array}$ \\
\hline
\end{tabular}

It was surprising that students are now not aware of the displacement concepts. It is the misconception among students and ignores the amount of volume taken by object when immersed in a volume of liquid.

The group of students responded that water level will go down. Their explanation was on treating volume increases on melting it will occupy less volume. The experiential learning activity motivates students to learn experimentally the concept and enable active participation of learners both mentally and physically.

On observation students are astonished that ice was floating in cup, was full to the brim and on melting waster did not overflow. Students observed till all the ice melted to believe the result. The students show the excitement about the state of dis-equilibrium.

Result in table-1 reveals that $20 \%(\mathrm{n}=10)$ has mis-conception on state of matter, theory of liquid and not able to explain concept of dis-placement. Students assumed that method of ice fitted space/volume net water liquid. The 60\% $(n=30)$ students correct understand concept of the displacement but $20 \%(\mathrm{n}=10)$ partially understood displacement and not able to recognize that ice does not displace all its volume and still above the water.

\section{Experiential Learning Activities: Two}

\section{Investigation of Impact of Melting Land Founded Ice on Rise of Sea Level.}

Cent percent $(n=50)$ interpret that water level in baking tray will increase. On melting ice from land will add melting water to tray. It added volume of water in sea. The ice melting drains water from land/mountain to sea. It causes rise in sea level. Teacher at this point explains students that why melting ice-berg do not cause a rise in sea level but melting glaciers and land-based ice-sheet cause rise in sea level.

\section{Experiential Learning Activities: Three Investing Impact of Heat on Sea Level}

The drive experiential learning activity 3 , researcher explains statistical data/interpretation about difference on how surface absorb heat due to climate change. The sea absorbs about $94 \%$ of heat trapped in atmosphere of each (Cook, 2011). Therefore it is significant to investigate how water behaves due to absorption of heat. 
Result of the study reveals that $40 \%(n=20)$ indicate that water will evaporate due to heat and sun will absorb water vapour. $60 \%(\mathrm{n}=30)$ predict that water level will increase. It was correct answer but lack of the association with thermal expansion is the reason behind rise in sea level.

All eight groups made right prediction. Three groups is related with increase in volume to practical expansion due to heat absorb. This is common misconception among students. The misconception is related to the theory of matter. It shows that experiential learning activity gives meaningful conclusion to real life experience. The scientific study must concrete real life experience for meaningful experience. It shows that Experiential learning activities may not always guarantee learning, understanding will take please. To acquire knowledge experiential learning activity with explanation, discussion, prediction will motivate learning environment. When straw kept in sun for about two hours the students observe the rise in level.

All eight groups able to explain sunlight make water particle to assimilate heat energy and expand. The students use theory of particle mater for expansion of particle was not in lib \ne but contradiction. When observation and prediction is not in line students learn to think critically during the experimental learning.

The result of the study shows that $30 \%$ indicate that both melting of land base ice in sea is significantly contributing to the rise in sea level. $41 \%$ students attribute that melting of land base ice contribute largely to rise in sea level. The $35 \%$ indicated that thermal expansion contributes largely to the rise in sea level.

No student's opinion that melting of ice/ floating ice contributes to the rise in sea level. It shows that students are able to correct their misconception about rise in sea level. In experiential learning activity all students confirm that melting of ice/iceberg is the cause of rise in sea level but none of the students indicate that ice berg has an effect on rise in sea level.

The most of students $80 \%$ was in the opinion that experiential learning activities have engaged inquisitiveness, participation and eagerness to learn about climate change concept. All students found that experiential learning activity is highly useful as it employs minds-on and hands on approach learning. The experiential learning activity encourages mental stimulation.

\section{Conclusion}

Experiential learning activity is useful strategy and effective in addressing misconception. It is effective pedagogical tool to provide experiential learning. Result of the study reveals that experiential learning improves, deepens, conceptual understanding of students about climate change experiential learning activity is minds-on/hands on activity which involves head, hand and heart. Experiential learning activity provides fun for learning and joyful learning experience. It encourages stimulate critical thinking.

\section{References}

[1] Barreda, A.B. (2018). Assessing the Level of Awareness on Climate Change and Sustainable Development among Students of Partido State University, Camarines Sur, Philippines. The Journal 
of Sustainability Education. Retrieved December 13, 2018 from www.susted.com/.../assessing-thelevel-ofawareness-on-climate-change-and-sustainab.

[2] Houghton, J.T. (2004). Global Warming-The Complete Briefing. Cambridge University Press. 216241.

[3] Parant, A.; Pascual, A.; Jugel, M.; Kerroume, M.; Felonneau, M.L.; Guéguen, N. Raising Students Awareness to Climate Change: An Illustration with Binding Communication. Environ. Behav. 2017, 49, 339-353. [CrossRef].

[4] Prashant Thote and Gowri. S, "Climate Change Inclusive Education School Curriculum", Review of Research, Volume 8, Issue 3, Dec 2018.

*Corresponding author.

E-mail address: prashant.thote@ rediffmail.com 